\title{
INQUILINISM BETWEEN THE CHEILODIPTERID FISH, APOGONICHTHYS PUNCTICULATUS, AND THE UNIVALVE MOLLUSK, STROMBUS BITUBERCULATUS
}

\author{
By E. W. Gudger
}

Bibliographer and Associate in Ichthyology, American Museum of Natural History, New York City.

(Figs. 264-265 incl.)

Symbiosis is, strictly speaking, the living together of two organisms for their mutual benefit, but in a more common and broader sense there are various kinds and degrees of this partnership in which fishes take part. Fishes live symbiotically with colonied hydroids, with medusae, and with sea anemones among the Coelenterates; with sea urchins, starfishes, and holothurians among Echinoderms; with other fishes; and last and possibly most infrequently with mollusks. In the latter category the most common living together is that of the pearlfish, Fierasfer, in the mantle cavity of the oyster, especially the pearl oyster, Meleagrina. But of symbiosis between a fish and a univalve mollusk one case only has thus far been recorded in the literature.

In 1908, L. Plate ${ }^{1}$ published an article on the symbiosis between a Cheilodipterid fish, Apogonichthys strombi, and a huge sea snail, Strombus gigas, in the Bahama Islands. It seems best to give a careful translation of his interesting account, and to follow this with my own observations.

After reciting various instances of symbiosis in which a fish is a partner, Plate sets forth as follows his observations made in January and February, 1905:-

The giant snail (Strombus gigas) is very abundant here and is brought in in great quantities by the market fishermen, as the foot of such "Conchs" finds a market both as food and as fish bait. It is considered a national dish, and the Bahama islanders - white as well as black-jokingly call themselves "Trueborn Conchs."

On the bottom of boats which had held a lot of snails, I often found a little brown fish from 3-6 cm. long. In answer to my questions, the fishermen explained that these animals were ejected by the snail as food waste. That this was an impossibility I proved absolutely on my trips in the vicinity of Nassau (New Providence) and on a longer voyage to the islands of Andros, Green Cay

${ }_{1}$ Plate, L. A pogonichthys strombi n.sp., ein symbiotisch lebender Fisch von den Bahamas. Zoologischer Anzeiger. 1908, Bd. XXXIII, pp. 393-399. 


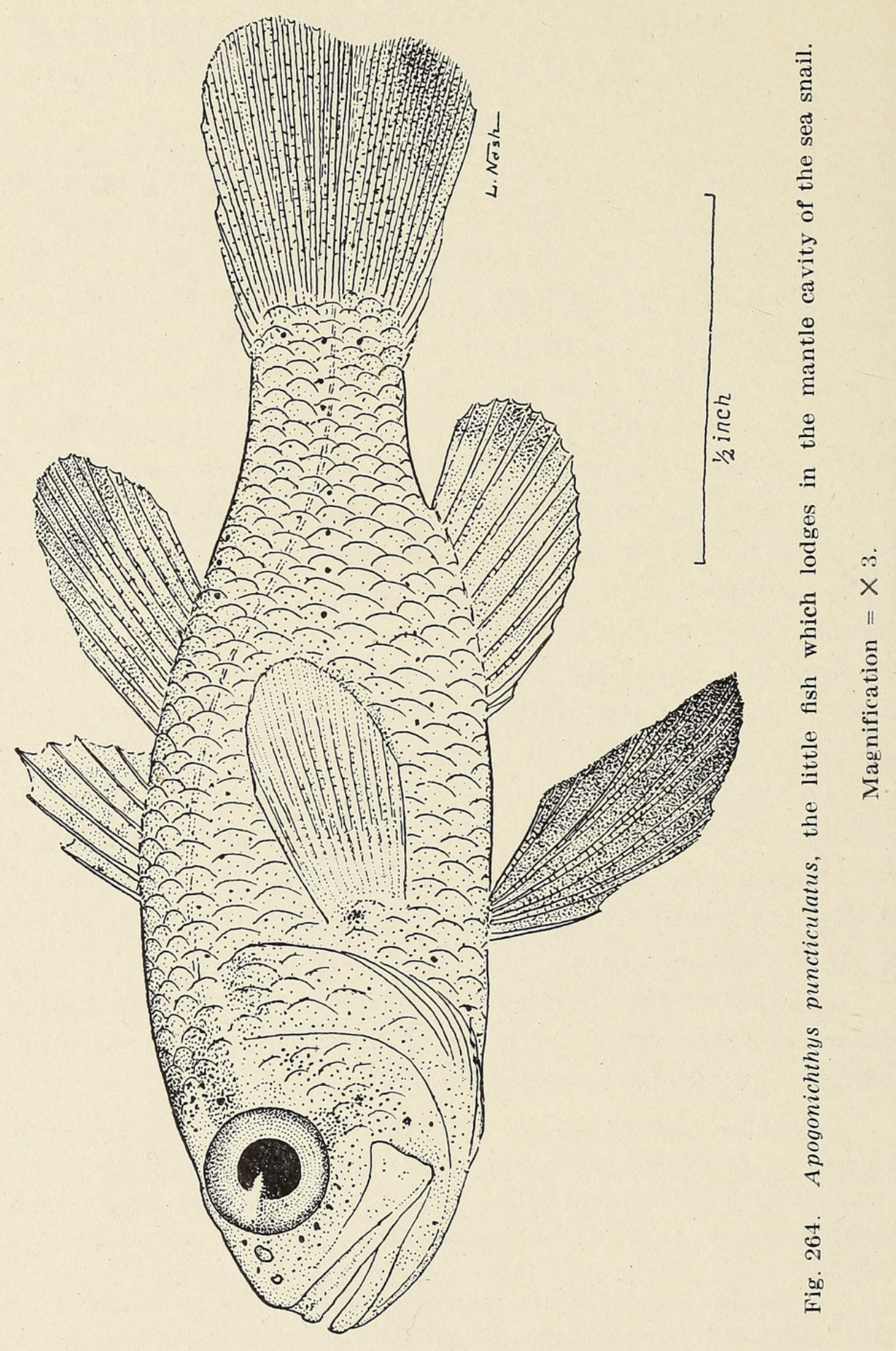


Exuma-Kette, Eleuthera and Egg Island. The small fishes live in the mantle cavity of the snail, but only in large specimens in water, from $2-5 \mathrm{~m}$. deep. The younger Strombus gigas, to a size as large as that of a fist, occur frequently in about a depth of $5 \mathrm{~m}$. here and there in the shallow coastal waters (for example, directly off Nassau), but I have never found a fish in one. I have often watched from a boat a large Strombus like this, but I have never seen it accompanied by any small fish. Moreover, none of a number of experienced fishermen, who in the course of their lives have captured many thousand snails, can recall any such observation. I conclude from this that the little fishes only abandon the snails at night to go after their food which consists of shrimps, sea-lice, and other crustaceans.

If one pulls up the snails by means of a long hook and lays them in the boat. the animals naturally first draw back into their shelter, but soon venture out a little way again. Whereupon the still living fishes slip out of the mantle cavity and can be kept alive if put into fresh water. If the snails lie in the boat from one to two hours and no fishes appear, one can be reasonably sure that they do not harbor any. I have never come across more than two tenants in one snail. In such cases, they proved to be sometimes a male and a female; sometimes the same sex. However, it was much more often the case that only one fish had sought shelter in the one snail. To be absolutely sure, I repeatedly put a fish and a snail together in a large sheet zinc receptacle and found in some cases that after a couple of hours, the fish had gone into the mantle cavity without my having seen it enter. In other cases, the fish stayed outside even after it had been a whole night in the same receptacle with the snail; perhaps because the water had grown too warm. I had no opportunity to place the creatures in a larger and well aired aquarium and thus to observe them under conditions approaching normal, so I cannot give any information on other peculiarities of this interesting symbiosis.

It still remains to determine the attitude of the snail toward the intruder, especially whether or not its entrance is welcome; moreover, whether the fish spawns inside or outside of the mantle cavity; whether it returns to the same snail which it has deserted in search of food, or whether it uses any snail in the vicinity; whether the fish swims far away from the snail, or always stays in its neighborhood, etc. In my judgment, the snail gains no advantage from its intruders, even as little as the previously mentioned organisms which are utilized by fishes (Holothurians, jelly fishes, sea roses and sea urchins). The question is not one of mutualism, but of a one-sided symbiosis.

The smallest example that I came across in a Strombus measured $32 \mathrm{~mm}$. from the tip of the snout to the base of the caudal fin, and was therefore almost full grown. Probably, therefore, the fish under these circumstances deposits its eggs outside the mantle cavity and the young animals do not live symbiotically. It will be easy to clear up all these questions at the biological station at Tortugas.

Shortly after the publication of Plate's article, my attention was called to it and when, in 1912, I began the first of several 


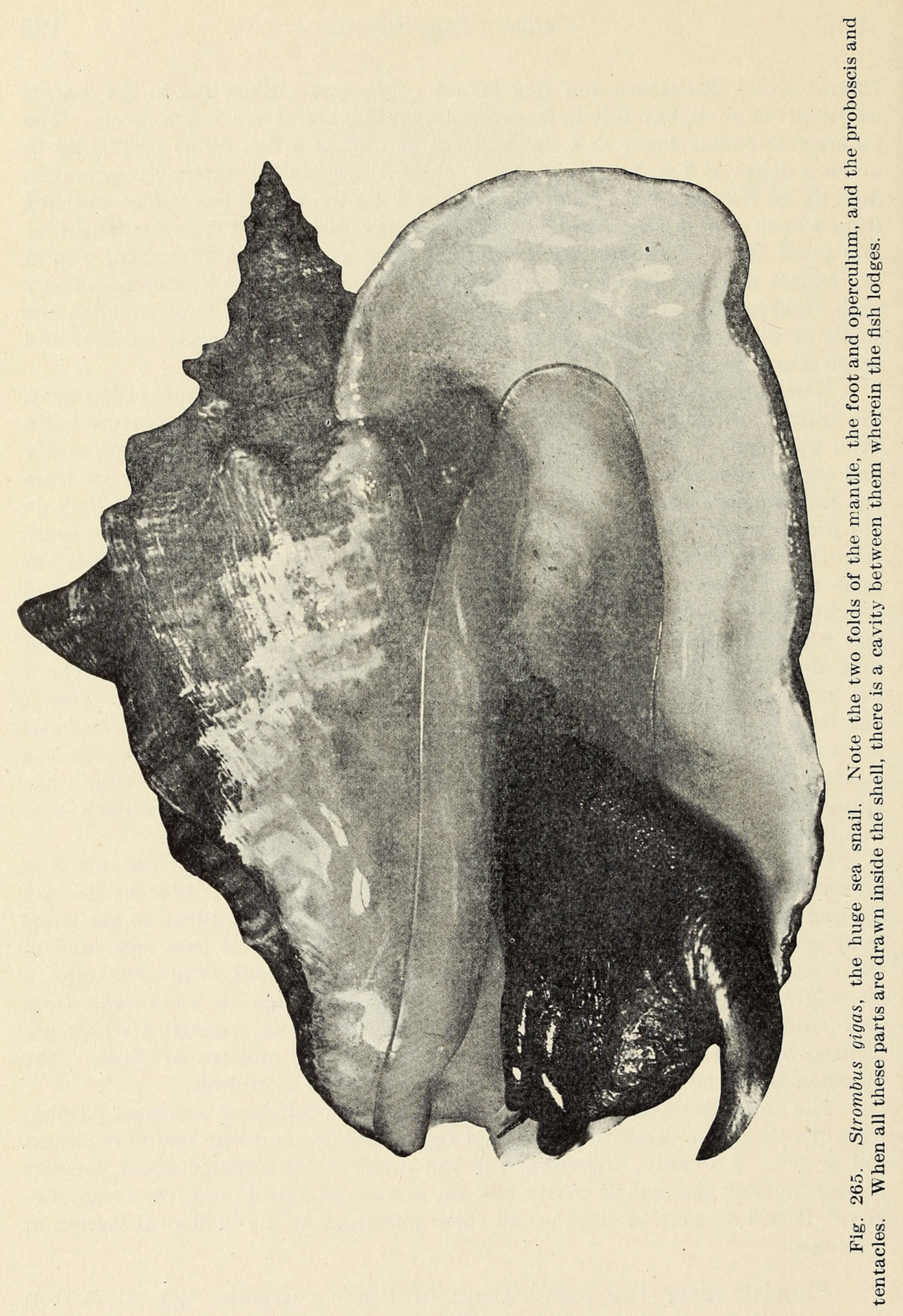


seasons' work at the laboratory of the Carnegie Institution of Washington at Tortugas, Florida, I sought for confirmation of Plate's find. Our engineers and boatmen, Florida- and Bahama-born, knew nothing of this phenomenon. Conchs were not easy to get, and the few examined revealed nothing out of the ordinary. My time and thoughts being concentrated on other work, the matter of this symbiosis presently was practically forgotten.

In 1914, however, the matter was brought sharply to the fore in the following manner. There was at the Tortugas laboratory that summer an investigator (Dr. E. E. Reinke) at work on the problem of sperm formation in Strombus bituberculatus. About the middle of July, the 'Dohrn' took the two of us to Key West, where Dr. Reinke hunted for his giant conchs while I fished for sharks. On our return we anchored for part of a day at Marquesas atoll where there was a good hunting ground for Strombus. Leaving a ship-keeper behind with the 'Dohrn,' the others of us went out in the launch on a great eel-grass flat to the southeast of the island where these mollusks abounded. The conchologist and I remained in and poled the launch along while the men waded over the flat in water about three feet deep and hunted for Strombus.

Presently these began to be handed or thrown into the boat, and little attention was paid to them. One conch, however, was laid on a seat with the aperture upward, and, on noticing it, great was our surprise to find a little fish swimming in the water which filled it. Since all the conchs found in the eel-grass were in the normal position for walking (mouth down), no conclusion was possible other than that the little fish had come up in the mantle cavity of the Strombus, that the conch, lying on its back so to speak, had thrust out its foot and operculum and had expelled some water and the fish with it. Then when the foot and connected parts had been retracted, the fish could not return to the deeper part of the cavity and was found swimming in the water remaining in the hollow of the shell outside the foot and operculum. Here then was confirmation of Plate's discovery.

These huge sea snails were taken to the ship and examined as carefully as possible. Next day at Tortugas they were stored in salt-water tanks awaiting Dr. Reinke's convenience. So far as observed, none gave up symbiont fish, and, although careful watch was made as they were dissected, in none were any fishes found. 
So, although Plate's discovery was confirmed in this symbiosis between a fish and a conch, both of different species from his forms, yet the questions he propounded in his article were not "easily cleared up at the biological station at Tortugas." Furthermore, though Dr. Reinke dissected considerable numbers of Plate's conch, Strombus gigas, from the Tortugas atoll, none were found to be inhabited by fishes. It should be noted, however, that one specimen of Apogonichthys puncticulatus has been taken at Tortugas, not in the mantle cavity of a conch but with dynamite at a depth of $35 \mathrm{ft}$. in West Channel. This at any rate proves that the fish is found at Tortugas, though it is plain that it occurs sparingly.

When classified, my little fish was found to be, as noted above, of a different species, i.e., Apogonichthys puncticulatus. It was 46 $\mathrm{mm}$. in total length, and $35 \mathrm{~mm}$. to the end of the spinal column (base of caudal fin). Plate fortunately gives a figure of his fish and from it my specimen differs markedly in a number of particulars, but especially in the size and color of the thoracically placed pelvic fins. A. strombi has these fins "darkish, almost black;" mine has them very black. In the first fish the pelvics are not very large and reach only to about the middle of the anal, while in my specimen they are enormously enlarged, and reach to the middle of the anal or even beyond this point. For these points see figure 264 .

My little fish was very shy, and, while kept in an aquarium of running salt water, mainly remained in hiding. However, when aroused it was a striking object as it swam around with its fan-like black pelvic fins widely spread.

Undoubtedly these little Apogonichthyids seek shelter and safety in the mantle cavity of their respective molluscan hosts, but it is a one-sided symbiosis for I cannot conceive how the mollusk can possibly benefit therefrom nor can I begin to answer the questions which Plate asked as he studied his specimens. However, it is something to have discovered another species of Apogonichthys which practices this habit.

Since the above was written, I have received an $\operatorname{article}^{2}$ relative to certain Key West fish in which Messrs. Hildebrand and Ginsburg announce the collection of four specimens of Apogonichthys stellatus

\footnotetext{
${ }^{2}$ Hildebrand, S. F., and Ginsburg, Isaac. 'Descriptions of Two New Species of Fishes from Key West, Fla., with notes on Nine Other Species Collected in the Same Locality.' Bulletin United States Bureau of Fisheries, 1926, Vol. 42, p. 210, fig.
} 
from conchs at Key West. These measure 42, 43 (2 specimens) and $50 \mathrm{~mm}$. long. They were taken Dec. 8, Jan. 1, Feb. 1, and April 27. Now, many of these Cheilodipterid fishes practice oral gestation but, as none had eggs in their mouths, the dates given are presumably not the breeding season and this precludes the idea I once had that possibly the fishes live in the mouth cavity of the conch for protection during the breeding season. The particular species of conch was not determined.

Hildebrand and Ginsburg identify their fishes with Cope's species, Apogonichthys stellatus, established in 1869. Cope's description, however, contained a number of errors which Fowler in 1907 corrected, giving an excellent figure. Hildebrand and Ginsburg further compare Plate's figure and description with the above and decide that his fish also is A. stellatus. There can be no doubt, however, that my fish is a different species.

The American Museum has a beautiful model of Strombus gigas with the anterior part of the animal protruding from the aperture of the shell. This is reproduced herein as Fig. 265. Here may be seen the folds of the mantle lining both sides of the aperture, the contracted relatively small foot with the operculum at its hinder end, in front of this the large black proboscis with the tentacles on either side. When these are drawn in to fill the outer part of the aperture, there is left a water-filled space between the body and the mantle, and in this the fish is contained.

Mr. C. E. Olsen, a skilled preparator in the American Museum, accompanied Dr. R. W. Miner on an expedition to the Bahamas in July 1926, and there observed this phenomenon. He tells me that at one spot off Mangrove Cay, Andros Island, large numbers of Strombus gigas were brought aboard and thrown in the bottom of the boat. Presently he noticed many small fishes swimming about in the water. So abundant were they that he believes that each conch must have given up a fish. Conchs from other localities did not happen to have fish. This would lead to the idea that the phenomenon is rather localized. The Bahamans call these fishes "conch-fishes."

In conclusion, it may be said that Mr. L. L. Mowbray, formerly of the New York Aquarium but now head of the Bermuda institution, tells me that he has repeatedly observed this phenomenon in the Bahamas. Unfortunately however, he did not identify the 
fishes; but, with two species known to practice this habit, one is lead to wonder if other species of the genus do not do likewise.

\section{SUMMARY}

Plate in 1905 discovered, and in 1908 first made known this curious form of association between a Cheilodipterid fish, Apogonichthys strombi (stellatus) and the sea snail, Strombus gigas. Gudger in 1914, discovered a similar relationship between Apogonichthys puncticulatus and Strombus bituberculatus. In 1922-23, Ginsburg collected four specimens of Apogonichthys stellatus from conchs at Key West, and in 1918-1919, three from cavities in sponges in the same locality. Probably other species of this genus will be found to have similar habits.

No explanation is at hand for this remarkable form of association in which the fish gains a sure protection but in which no value for the conch seems possible. It is not a strict symbiosis, nor a commensalism, nor a mutualism. Perhaps the most fitting term is inquilinism (a lodging secured by one party), a term already in use for such a one-sided association among insects and proposed by Emery to describe the relationship between the pearlfish, Fierasfer and its bivalve molluscan host, the pearl oyster, Meleagrina. 


\section{$2 \mathrm{BHL}$ Biodiversity Heritage Library}

Gudger, E. W. 1927. "Inquilinism between the cheilodipterid fish, Apogonichthys puncticulatus, and the univalve mollusk, Strombus bituberculatus." Zoologica : scientific contributions of the New York Zoological Society 9(2), 193-200. https://doi.org/10.5962/p.203742.

View This Item Online: https://www.biodiversitylibrary.org/item/208079

DOI: https://doi.org/10.5962/p.203742

Permalink: https://www.biodiversitylibrary.org/partpdf/203742

\section{Holding Institution}

Smithsonian Libraries

\section{Sponsored by}

Biodiversity Heritage Library

\section{Copyright \& Reuse}

Copyright Status: In Copyright. Digitized with the permission of the rights holder

Rights Holder: Wildlife Conservation Society

License: http://creativecommons.org/licenses/by-nc/3.0/

Rights: https://www.biodiversitylibrary.org/permissions/

This document was created from content at the Biodiversity Heritage Library, the world's largest open access digital library for biodiversity literature and archives. Visit BHL at https://www.biodiversitylibrary.org. 